\title{
Single mothers: their health and health service use
}

\author{
P BEATSON-HIRD, P YUEN, AND R BALARAJAN \\ From the Epidemiology and Public Health Research Unit, University of Surrey, Guildford, Surrey, UK.
}

\section{ABSTRACT}

Study objective: The aim of the study was to investigate differences in reported health and health service use in single mothers.

Design: The study was a survey of data derived from the General Household Surveys conducted by the Office of Population Censuses and Surveys (OPCS).

Setting: The OPCS data are derived from samples of households throughout Great Britain.

Participants: OPCS data for 1983 and 1984 were used, comprising approximately 60000 individuals, of whom 793 were single mothers.

Measurements and main results: Five different health outcomes were examined, two on perceived morbidity and three on the use of health services. The chief determinants of health and health services use among single mothers were housing tenure, employment status and the age of the youngest child. Single mother status did not consistently contribute to self reported morbidity and uptake of care when adjusted for other social variables, but there was a difference between categories of single mother, with those who were separated/divorced and those who were widowed reporting more acute illness than those who were married.

Conclusion: The findings suggest that single mothers do not form a homogeneous group and that, if special consideration is to be given to them when planning and allocating health service resources, this needs to be taken into account in the context of other socioeconomic factors.

The number of single parent families increased by $12 \%$ between 1979 and 1984 resulting in an estimated 940000 single parent families in Britain with 1.5 million dependent children. ${ }^{1}$ More than $90 \%$ of single parent families are headed by a lone mother.

The single parent family has characteristics distinct from other family forms, in that the family has available the resources of one as opposed to two adult members. In particular the causes of stress differ qualitatively and quantitatively from those found in other family types. ${ }^{2}$ The female head of the family has been described as being "overworked, overstressed and often so depressed". 3

One would therefore expect to find some effects of single parent status on health and health service use. This study aimed to examine the differences in reported health and health service use between single mothers-those never married, separated or divorced, or widowed-using data from the 1983 and 1984 General Household Surveys. ${ }^{45}$

\section{Methods}

The General Household Survey is a probability sample survey conducted annually by the Office of
Population Censuses and Surveys of those living in private households. Each year approximately 30000 individuals from about 12000 households in Great Britain are interviewed on a wide range of topics such as employment, income, leisure and health.

Data for 1983 and 1984 were used for this study and they were merged to increase the sample size, particularly the number of single parent families. Five different health outcomes were examined; two on perceived morbidity (self reported acute and chronic illness) and three on the use of health services (consultation with a doctor, inpatient admission inclusive of maternity admissions, and attendance at an outpatient or accident and emergency department). Acute illness was defined as that which caused restriction of the respondent's normal level of activity in the $\mathbf{1 4}$ days prior to the interview. Chronic illness was defined as any longstanding illness, disability or infirmity that limited a person's overall activity level. Measures of uptake of health care covered consultation with a doctor in the previous two weeks; attendance at an outpatient or accident and emergency department in the previous three months; and inpatient admission in the previous year.

To explain variations of each health outcome 
among mothers seven potential explanatory variables were studied. These included both personal variables (age of mother, the number of dependent children and age of her youngest child) and social variables (housing tenure, employment or economic status, socioeconomic group and presence or absence of further education).

Only mothers with dependent children were included in the study and grouped into one of six different age groups (16-24, 25-29, 30-34, 35-39, 40-44, and 45-64 years). The age of the youngest child was classified into one of four groups $(<1,1-4,5-9$, and 10-15 years) and the number of dependent children into three groups (1, 2 or 3 and more).

The single mothers were categorised into single never married, divorced, separated and widowed. However preliminary analysis suggested that the divorced and separated groups could be considered together and that socioeconomic groups could be grouped into manual and non-manual groups. The economic status categories were: working, which included those waiting to start a job; unemployed; housewives; and "others". The latter included full time or part time students, seasonal workers and unpaid women working in their family business. Further education was defined as education, either full time or part time, since leaving school. Housing tenure was examined in three groups, namely owner occupier, council or private tenant.
Stepwise multiple logistic regression ${ }^{6}$ was used to model the probability of a particular health outcome with respect to the explanatory variables. The statistical package BMDP $^{7}$ selects variables in a stepwise manner, based on their overall contribution to the model. To enable the comparison between the single and married mothers, marital status is always included in the final model selected. Odds ratios and their approximate $95 \%$ confidence intervals (CI) were calculated.

\section{Results}

\section{SAMPLE CHARACTERISTICS}

There were 6440 mothers with dependent children in the surveys of 1983 and 1984 combined, of whom $88 \%$ were married, $8 \%$ were separated or divorced, $3 \%$ were single never married and $1 \%$ were widowed. The age distribution varied considerably by marital status with $55 \%$ of single never married mothers being in the age group 16-24 years, compared to less than $10 \%$ of married, widowed, separated or divorced mothers. Widowed mothers formed an older age group with $70 \%$ being 40 years of age or more. Married and separated or divorced mothers had similar age distributions (figure).

Single never married mothers had younger children than other marital groups with $72 \%$ of them having children aged less than 5 years. Sixty five percent of

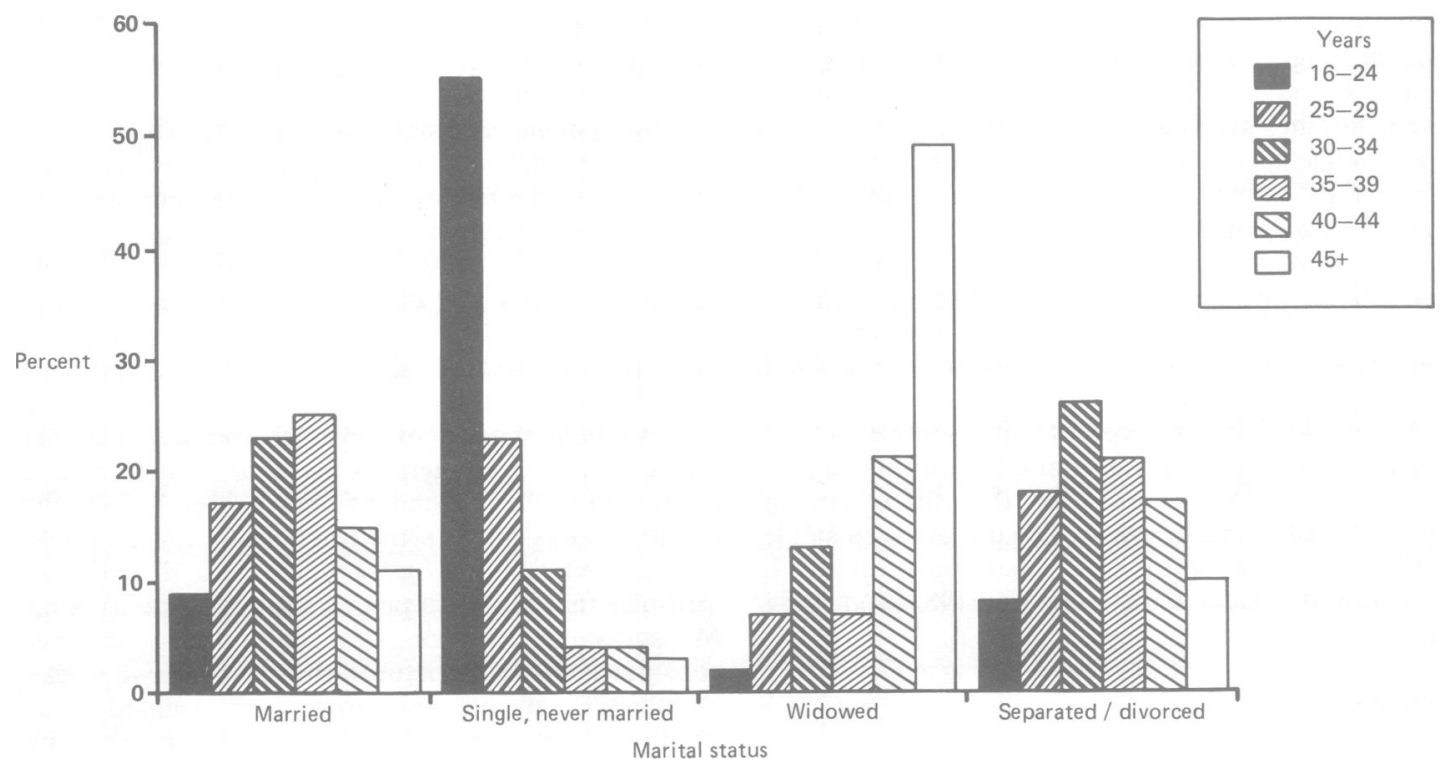

Figure Age distribution of mothers by marital status, General Household Surveys, 1983-4. 
widowed mothers and $43 \%$ of divorced or separated mothers had children aged 10-15 years, this being lower in married $(33 \%)$ and single never married mothers $(10 \%)$. The number of dependent children varied by marital status. Seventy four percent of single never married mothers had only one dependent child compared to $36 \%$ of married mothers.

Sixty six percent of married mothers lived in their own homes compared to only $13 \%$ of single never married mothers, $76 \%$ of whom lived in council accommodation. Widowed mothers were equally distributed in council and owner-occupier housing whereas two thirds of separated or divorced mothers were council tenants. There were no major differences in employment status between married, widowed, separated or divorced mothers, with approximately $40 \%$ in each category working. Among single never married mothers, $60 \%$ described themselves as housewives with only $16 \%$ in employment. There were more married mother $(55 \%)$ in the non-manual group and fewer single never married (38\%). Seventy four percent of single never married mothers had no further education since leaving school. Widowed, separated or divorced mothers were all similar in the extent of their further education and married mothers had the most further education (43\%).

\section{HEALTH STATE}

Self reported acute illness-The reporting of acute illness varied by marital status with married and single never married mothers reporting a lower rate $(12 \%)$ than widowed mothers $(21 \%)$ and separated or divorced mothers $(20 \%)$ (table 1). However, using logistic analysis to derive a model, after allowing for explanatory variables, only the separated or divorced mothers were found to have a significantly higher adjusted odds ratio (OR) for acute illness $(\mathrm{OR}=1 \cdot 71$, $95 \% \mathrm{CI}=1 \cdot 33-2 \cdot 19)$ when compared to married mothers (table 2). Housing tenure was an important determinant of acute illness, with council tenants having a higher odds ratio $(\mathrm{OR}=1 \cdot 32,95 \% \mathrm{CI}=1 \cdot 09$ 1.59). Those who had received further education since

Table 1 Percentage distribution of self reported illness and uptake of health care by marital status of mother

\begin{tabular}{lcccc}
\hline & Married & $\begin{array}{l}\text { Single } \\
\text { never } \\
\text { married }\end{array}$ & Widowed & $\begin{array}{l}\text { Divorced } \\
\text { separated }\end{array}$ \\
\hline Acute illness & 12 & 12 & 21 & 20 \\
Chronic illness & 23 & 25 & 48 & 32 \\
Consultation with doctor & 17 & 20 & 21 & 19 \\
Outpatient attendance & 10 & 7 & 15 & 14 \\
Inpatient admission & 19 & 31 & 7 & 16 \\
(Base $=100 \%$ & 5647 & 195 & 85 & $513)$ \\
\hline
\end{tabular}

Table 2 Age adjusted odds ratios for self reported acute illness, General Household Surveys 1983-4.

\begin{tabular}{|c|c|c|c|}
\hline & & $\begin{array}{l}\text { Odds } \\
\text { ratio }\end{array}$ & $\begin{array}{l}95 \% \\
\text { Confidence } \\
\text { intervals }\end{array}$ \\
\hline Marital status & $\begin{array}{l}\text { Married } \\
\text { Single never married } \\
\text { Separated/divorced } \\
\text { Widowed }\end{array}$ & $\begin{array}{l}1.00 \\
0 \cdot 89 \\
1 \cdot 71 \\
1.52\end{array}$ & 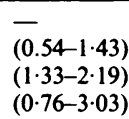 \\
\hline Tenure & $\begin{array}{l}\text { Owner-occupier } \\
\text { Private tenant } \\
\text { Council tenant }\end{array}$ & $\begin{array}{l}1.00 \\
0 \cdot 86 \\
1 \cdot 32\end{array}$ & $\begin{array}{l}- \\
(0 \cdot 62-1 \cdot 19) \\
(1 \cdot 09-1 \cdot 59)\end{array}$ \\
\hline $\begin{array}{l}\text { Further education } \\
\text { since leaving } \\
\text { school }\end{array}$ & $\begin{array}{l}\text { No } \\
\text { Yes }\end{array}$ & $\begin{array}{l}1 \cdot 00 \\
1 \cdot 28\end{array}$ & $\overline{(1.09-1 \cdot 52)}$ \\
\hline
\end{tabular}

leaving school reported higher rates of acute illness than those who had no further education $(O R=1 \cdot 28$, $95 \% \mathrm{CI}=1 \cdot 09-1 \cdot 52$ ).

Self reported chronic illness-The distribution of chronic illness also varied with marital status. The divorced or separated $(32 \%)$ and particularly widowed mothers (48\%) (table 1) experiencing more chronic illness than married mothers $(23 \%)$. However in the process of modelling, marital status did not show significant contribution towards the effect on the presence of chronic illness, though the odds ratios derived from the final model with marital status forced into it were raised in all categories of single mothers (table 3). Housing tenure influenced chronic illness with council tenants having a significantly higher odds ratio $(\mathrm{OR}=1.42,95 \% \mathrm{CI}=1 \cdot 23-1 \cdot 65)$ than owner-

Table 3 Age adjusted odds ratios for self reported chronic illness, General Household Surveys 1983-4.

\begin{tabular}{|c|c|c|c|}
\hline & & $\begin{array}{l}\text { Odds } \\
\text { ratio }\end{array}$ & $\begin{array}{l}95 \% \\
\text { Confidence } \\
\text { intervals }\end{array}$ \\
\hline Marital status & $\begin{array}{l}\text { Married } \\
\text { Single never married } \\
\text { Separated/divorced } \\
\text { Widowed }\end{array}$ & $\begin{array}{l}1 \cdot 00 \\
1 \cdot 17 \\
1 \cdot 19 \\
1 \cdot 63\end{array}$ & $\begin{array}{l}- \\
(0 \cdot 80-1 \cdot 70) \\
(0 \cdot 95-1 \cdot 48) \\
(0 \cdot 94-2 \cdot 82)\end{array}$ \\
\hline Tenure & $\begin{array}{l}\text { Owner-occupier } \\
\text { Private tenant } \\
\text { Council tenant }\end{array}$ & $\begin{array}{l}1.00 \\
1.07 \\
1.42\end{array}$ & $\begin{array}{l}\overline{(0 \cdot 84-1.37)} \\
(1 \cdot 23-1.65)\end{array}$ \\
\hline $\begin{array}{l}\text { Age of youngest } \\
\text { child (years) }\end{array}$ & $\begin{array}{l}10-15 \\
5-9 \\
1-4 \\
<1\end{array}$ & $\begin{array}{l}1.00 \\
1.01 \\
0.77 \\
0.63\end{array}$ & $\begin{array}{l}- \\
(0 \cdot 85-1.20) \\
(0.63-0.94) \\
(0.47-0.84)\end{array}$ \\
\hline Economic status & $\begin{array}{l}\text { Working } \\
\text { Unemployed } \\
\text { Housewife } \\
\text { Othert }\end{array}$ & $\begin{array}{l}1 \cdot 00 \\
1 \cdot 38 \\
1 \cdot 33 \\
1 \cdot 50\end{array}$ & $\begin{array}{l}- \\
(1 \cdot 01-1 \cdot 88) \\
(1 \cdot 16-1 \cdot 53) \\
(0 \cdot 79-2 \cdot 83)\end{array}$ \\
\hline
\end{tabular}

t See text 
occupiers or private tenants. The age of the youngest child determined the reporting of chronic illness with increasing odds ratios with age of child. Unemployed mothers and housewives had significantly higher odds ratios for chronic illness. Those of the "other" category were also higher but not significantly so.

\section{USE OF HEALTH SERVICES}

Consultation with a doctor-Percentage of mothers consulting a doctor did not vary substantially with marital status (table 1) and this was confirmed by the corresponding logistic regression model (table 4). However, economic status, housing tenure, the age of the youngest child and the number of dependent children appeared to be determinants of whether a mother had consulted with a doctor. Housewives had a significantly higher adjusted odds ratio $(\mathrm{OR}=1 \cdot 22$, $95 \% \mathrm{CI}=1.05-1.43)$ than working mothers and council tenants had a higher adjusted odds ratio $(\mathrm{OR}=1.25, \quad 95 \% \quad \mathrm{CI}=1.06-1.46)$ than owner occupiers and private tenants. Consultation with a doctor decreased with increasing age of the child and increased with decreasing family size.

Table 4 Age adjusted odds ratios for consultation with a doctor, General Household Surveys 1983-4.

\begin{tabular}{|c|c|c|c|}
\hline & & $\begin{array}{l}\text { Odds } \\
\text { ratio }\end{array}$ & $\begin{array}{l}95 \% \\
\text { Confidence } \\
\text { intervals }\end{array}$ \\
\hline Marital status & $\begin{array}{l}\text { Married } \\
\text { Single never married } \\
\text { Separated/divorced } \\
\text { Widowed }\end{array}$ & $\begin{array}{l}1 \cdot 00 \\
0 \cdot 78 \\
1 \cdot 11 \\
0.79\end{array}$ & $\begin{array}{l}(0.53-1 \cdot 16) \\
(0.86-1.43) \\
(0.37-1.67)\end{array}$ \\
\hline $\begin{array}{l}\text { Age of youngest } \\
\text { child (years) }\end{array}$ & $\begin{array}{l}10-15 \\
5-9 \\
1-4 \\
<1\end{array}$ & $\begin{array}{l}1 \cdot 00 \\
1 \cdot 22 \\
1 \cdot 31 \\
1 \cdot 68\end{array}$ & $\begin{array}{l}(0.99-1.52) \\
(1.03-1.67) \\
(1.25-2.26)\end{array}$ \\
\hline Economic status & $\begin{array}{l}\text { Working } \\
\text { Unemployed } \\
\text { Housewwife } \\
\text { Othert }\end{array}$ & $\begin{array}{l}1 \cdot 00 \\
1 \cdot 08 \\
1 \cdot 22 \\
1 \cdot 23\end{array}$ & $\begin{array}{l}- \\
(0.76-1.52) \\
(1.05-1.43) \\
(0.59-2.59)\end{array}$ \\
\hline Tenure & $\begin{array}{l}\text { Owner-occupier } \\
\text { Private tenant } \\
\text { Council tenant }\end{array}$ & $\begin{array}{l}1 \cdot 00 \\
0.97 \\
1 \cdot 25\end{array}$ & $\begin{array}{l}\overline{(0.74-1.26)} \\
(1.06-1.46)\end{array}$ \\
\hline $\begin{array}{l}\text { No of dependent } \\
\text { children }\end{array}$ & $\begin{array}{l}1 \\
2 \\
3 t\end{array}$ & $\begin{array}{l}1.00 \\
0.81 \\
0.73\end{array}$ & $\begin{array}{l}- \\
(0.70-0.95) \\
(0.59-0.90)\end{array}$ \\
\hline
\end{tabular}

tSee text

Outpatients or accident and emergency attendanceOverall percentage attending outpatient or Accident and Emergency departments varied with marital status with widowed mothers $(15 \%)$ attending the most and single never married mothers the least $(7 \%)$. When allowing for explanatory variables in the model, the main determinants of outpatient attendance were the age of the youngest child and economic status (table 5). Mothers with a child under one year had a significantly lower adjusted odds ratio for outpatient visits $(\mathrm{OR}=0.49,95 \% \mathrm{CI}=0.35-0.71)$ but those in the "other" economic status group had an increased odds ratio $(\mathrm{OR}=2 \cdot 34,95 \% \mathrm{CI}=1 \cdot 15-4 \cdot 78)$.

Table 5 Age adjusted odds ratios for outpatients and accident attendance, General Household Surveys 1983-4.

\begin{tabular}{|c|c|c|c|}
\hline & & $\begin{array}{l}\text { Odds } \\
\text { ratio }\end{array}$ & $\begin{array}{l}95 \% \\
\text { Confidence } \\
\text { intervals }\end{array}$ \\
\hline Marital status & $\begin{array}{l}\text { Married } \\
\text { Single never married } \\
\text { Separated/divorced } \\
\text { Widowed }\end{array}$ & $\begin{array}{l}1 \cdot 00 \\
0 \cdot 75 \\
1 \cdot 20 \\
1 \cdot 08\end{array}$ & $\begin{array}{l}- \\
(0.43-1 \cdot 32) \\
(0.90-1 \cdot 59) \\
(0.49-2 \cdot 40)\end{array}$ \\
\hline $\begin{array}{l}\text { Age of youngest } \\
\text { child (years) }\end{array}$ & $\begin{array}{l}10-15 \\
5-9 \\
1-4 \\
<1\end{array}$ & $\begin{array}{l}1.00 \\
0.98 \\
0.81 \\
0.49\end{array}$ & $\begin{array}{l}\overline{(0.79-1.21)} \\
(0.65-1.01) \\
(0.35-0.71)\end{array}$ \\
\hline Economic status & $\begin{array}{l}\text { Working } \\
\text { Unemployed } \\
\text { Housewife } \\
\text { Othert }\end{array}$ & $\begin{array}{l}1 \cdot 00 \\
1 \cdot 32 \\
1 \cdot 19 \\
2 \cdot 34\end{array}$ & $\begin{array}{l}- \\
(0.88-1.98) \\
(0.99-1.43) \\
(1 \cdot 15-4.78)\end{array}$ \\
\hline
\end{tabular}

†See text

Inpatient admissions - In percentage terms, twice as many single never married mothers $(31 \%)$ experienced inpatient admissions in the year previous to interview than separated or divorced mothers $(16 \%)$. The lowest admission rate was amongst widowed mothers $(7 \%)$ (table 1). As inpatient admissions include maternity admissions the results are likely to be strongly influenced towards mothers with children under the age of one year. Thus in modelling inpatient

Table 6 Age adjusted odds ratios for inpatient admissions, General Household Surveys 1983-4.

\begin{tabular}{llll}
\hline & & $\begin{array}{l}\text { Odds } \\
\text { ratio }\end{array}$ & $\begin{array}{l}95 \% \\
\text { Confidence } \\
\text { intervals }\end{array}$ \\
\hline Marital status & Married & 1.00 & - \\
& Single never married & 1.09 & $(0.74-1.89)$ \\
& Separated/divorced & 1.32 & $(0.98-1 \cdot 77)$ \\
Widowed & 0.50 & $(0.15-1 \cdot 59)$ \\
Tenure & Owner-occupier & 1.00 & - \\
& Private tenant & 1.16 & $(0.82-1.64)$ \\
Economic status & Council tenant & 1.33 & $(1.08-1.64)$ \\
& Working & 1.00 & - \\
& Unemployed & 1.34 & $(0.86-2.08)$ \\
& Housewife & 1.36 & $(1.13-1.65)$ \\
& Othert & 2.29 & $(1.05-5.55)$ \\
\hline
\end{tabular}

t See text 
admissions we excluded those mothers who had a youngest dependent child of under one year. The main determinants of inpatient admissions were housing tenure and economic status. Separated or divorced mothers had a higher adjusted odds ratio for hospital inpatient admissions $(\mathrm{OR}=1 \cdot 32,95 \% \mathrm{CI}=0.98-1 \cdot 77)$ and for single never married mothers the odds ratio was slightly raised (table 6). Mothers living in council housing had a significantly higher odds ratio $(\mathrm{OR}=1.33,95 \% \mathrm{CI}=1.08-1.64)$ for inpatient admissions than owner occupier or private tenants.

\section{Discussion}

The General Household Survey collects data on many social variables and provides the opportunity to link these with the information collected on the health status and health service use. It remains a unique source of data covering aspects of morbidity and social factors on a large representative population sample in the country.

The health aspects cover data on self reported health experience and health service use. A person's assessment of his own health is almost certainly less than a perfect reflection of his actual clinically measured health status. Nevertheless Maddox and Douglas $^{89}$ argued the usefulness of self ratings of health in situations in which clinical assessment is impossible or impractical. They showed that physician and patient ratings of health were consistently correlated and these results are in agreement with those of other investigators. ${ }^{10}$

However, there are limitations of the General Household Survey pertinent to this study. Firstly the number of widowed mothers is very small, being only $1 \%$ of the total sample. Secondly, as the survey covers only those in private households, the single never married mothers living in hostels or other institutional accommodation are not included.

Our findings for 1983 and 1984, showed that the chief determinants of health and health service use amongst women with dependent children were housing tenure, employment status and the age of their youngest child. Four out of the five health outcomes studied were strongly influenced by each of these variables. Marital status itself was relatively less important, showing non-significant contributions towards the pattern of self reported chronic illness, consultation with a doctor or outpatient visits. Higher odds ratios were seen consistently only among separated or divorced mothers with significant excess only for acute illness, and the odds ratio for inpatient admissions showed marginal significance after allowing for other social variables.

Ill health itself could lead to a change in marital status and this could explain some of the increase in inpatient admissions among separated or divorced mothers. Stress experienced through marital breakdown could also have contributed to the increased reporting of acute illness though the maximum period of stress and its adverse effects on health has been shown to occur prior to the divorce action itself. ${ }^{11} 12$

The characteristics of this sample of mothers varied greatly with marital group. In allowing for these different characteristics within each marital group it is evident that the residual effect of marital status per se on health and health service use is lowered. Other studies appear not to have taken these different characteristics into account when considering the effect of marital status on morbidity. There appear to be no published articles in which the effect of social variables, including marital status, on health and health service use in single mothers have been quantified.

Socioeconomic group is usually regarded as an unreliable classification for women since many, particularly those of younger age groups, may never have worked. This is reflected in our findings, in that socioeconomic group was not a significant determinant of any health outcome. In contrast housing tenure, a better proxy measure of social status of women, was a significant determinant in four of the five indicators studied.

Both the unemployed and those who were housewives reported chronic illness more and experienced greater levels of inpatient admissions. The higher consultation rates among housewives may represent an element of opportunity over those in employment. It is also not surprising that employment status was a significant determinant of health outcome in that the healthier members of the population are more likely to be working than those with illness. The presence or absence of further education since leaving school assumed little importance in determining health outcome, except for acute illness where those who had received higher education had the highest rates. This could represent the greater expectation of health amongst those with further education or underreporting of higher threshold of acute illness in those with no further education experience.

It has been suggested that the distribution of single parent families ought to be taken into account in planning health services as single parents with dependent children are more socially disadvantaged. ${ }^{1314}$ Our findings show that the differences are reduced when the other social variables are allowed for, especially housing tenure and economic status. The entity of single parent status is also not homogeneous and the distribution within this category ought to be carefully considered. In health care planning and resource allocation, if allowances are to be given for the prevalence of single parent 
families they ought to be considered in the context of socioeconomic factors as otherwise there could be an element of double counting.

Address for correspondence and reprints: $\mathrm{Dr} \mathbf{R}$ Balarajan, Director, Epidemiology and Public Health Research Unit, University of Surrey, Guildford, Surrey GU2 5XH, UK.

\section{References}

${ }^{1}$ Haskey J. One-parent families in Great Britian. Population Trends 1986; 45: 5-13.

${ }^{2}$ Duffy ME. When a woman heads a household. Nursing Outlook 1982; 30(8): 468-73.

${ }^{3}$ Weltner JS. A structural approach to the single parent family. Family Process 1982; 21: 203-10.

${ }^{4}$ Office of Population Censuses and Surveys. General household survey 1983. London: Her Majesty's Stationery Office, 1985.
${ }^{5}$ Office of Population Censuses and Surveys. General household survey 1984. London: Her Majesty's Stationery Office, 1986.

6 Cox DR. Analysis of binary data. London: Methuen, 1970.

${ }^{7}$ BMDP statistical software. Berkeley, CA: University of California Press, 1983.

${ }^{8}$ Maddox Gl, Douglas EB. Self-assessment of health: a longitudinal study of elderly subjects. J Health Soc Behav 1973; 14: 87-93.

9 Maddox GL. Self-assessment of health status. J Chron Dis 1964; 17: 449-60.

${ }^{10}$ Palmore E, Linkhart C. Health and social factors related to life satisfaction. J Health Soc Behav 1972; 13: 68-70.

${ }^{11}$ Chester R. Health and marriage breakdown: experience of a sample of divorced women. Br J Prev Soc Med 1971; 25: 231-5.

12 Dominian J. Definition and extent of marital pathology. Br Med J 1979; ii: 478-9.

${ }^{13}$ Department of Health and Social Security. Assessing target allocations within the Thames Regions: Report of a working group. London: DHSS, 1979.

$14 \mathrm{Jarman} \mathrm{B}$. Identification of underprivileged areas. Br Med J 1983; 286: 1705-9.

Accepted for publication May 1989 